\title{
European oak decline phenomenon in relation to climatic changes
}

\author{
Nenad Keča ${ }^{1} \bowtie$, Ioannis Koufakis ${ }^{2}$, Jana Dietershagen ${ }^{2}, J_{\text {Justyna A. Nowakowska }}^{2}$, \\ Tomasz Oszako ${ }^{3}$ \\ ${ }^{1}$ University of Belgrade, Faculty of Forestry, Department of Forestry, Kneza Višeslava 1, 11030 Belgrade Serbia, \\ phone: +38163580499, e-mail: nenad.keca@sfb.bg.ac.rs \\ ${ }^{2}$ Laboratory of Molecular Biology, Forest Research Institute, Sękocin Stary, 05-090 Raszyn, Poland \\ ${ }^{3}$ Białystok University of Technology, Forest Faculty, 17-200 Hajnówka, Poland
}

\section{Abstract}

The complex phenomenon of decline in European oak is currently triggered by changing climatic conditions and their consequences like heavy rains, local floods and pest development. Especially, pathogens from Phytophthora genus profit from soil saturation with water. They are alien invasive species, which attack and severely damage fine roots. In drought conditions occurring in the subsequent year, many oaks die as they encounter problem with water uptake. Additionally, insect defoliators followed by oak mildew infections accelerate the level of tree mortality. Secondary insects, butt and root pathogens are usually the final cause of death of many oaks. More research is needed in the direction to determine (i) measurable factors (e.g. chlorophyll florescence) that can indicate that the process of tree decline has already started, (ii) the correlation between the root decay and the crown symptoms (scanners, software), (iii) which combination of stressors stimulate the best development of pathogens that lead to the high plant mortality and (iv) the difference between the mortality caused by the native and the invasive Phytophthora species.

\section{KEY WORDS}

Quercus spp., Phytophthora, Armillaria spp., climate change, pathogen, pests

\section{INTRODUCTION}

The impact of recent global climate change has been well documented through changes in plant phenology, morphology and abundance (Richardson et al. 2013). Damages to forests caused by the extreme climatic events have also been well documented (Linder et al. 2010). The climate change scenarios for the 21 st centu- ry had predicted changes in the ecosystems, which will cause many difficulties for oaks to adopt and mitigate these new environmental conditions (Corcobado et al. 2014; Linder et al. 2010; Borja et al. 2008). During the 21 st century, the temperature will continue to raise (according to different scenarios) between 1.1 and $6.4^{\circ} \mathrm{C}$ (IPCC, 2007), causing many problems to plants and even more complex ecosystems such as forests. 
Plants are continuously affected by below- and above-ground abiotic and biotic stressors (Milanović et al. 2015). Because of the complexity of the forest ecosystems, it is becomes very complicated to hypothesise the effect of climatic changes, especially in an interaction between plants and their dependent communities of organisms (including pathogenic ones). The impact of climate change on plants and their interaction with herbivores and pathogens are usually based on models, because of lack of data or insufficient data about these changes (Poutasso et al. 2012; Milanović et al. 2015). The plant diseases driven by pathogens are expected to be exacerbated by the negative effect of weather extremes on forest ecosystems (Santini et al. 2013). The pathogen ecology is strongly dependent on environmental factors, such as temperature, moisture and changes in winter temperatures as a result of global warming. This can influence their distribution and development or even the pathogenicity. The negative effects have also been reported for herbivore and root-damaging insects (Masters et al. 1993).

This review focuses on the importance of climatic changes and how they directly (changing weather conditions) and indirectly (increased pest and diseases) affect the European oak tree populations. Different causes of the oak decline phenomena are mentioned and discussed in this review.

\section{Drought AND water logging}

The whole of Europe will be, according to climate model simulation, under pronounced periods of droughts and/or water logging (Linder et al. 2010, Potausso et al. 2012, Portz et al. 2011). These two factors cause stress and increase the vulnerability of oak trees, which are among the most valuable broadleaved trees in Europe. The different stages of oak stands affected by the phenomenon of decline were observed in the last decade throughout Europe. The complexity of oak decline process and spectra of involved biotic agents were reviewed by Oszako and Delatour in "Recent advances in oak health in Europe" (Oszako and Delatour 2000). The main biotic factors involved in oak decline are root pathogens (Armillaria and Phytophthora species) and insect defoliators.

\section{FACTORS AFFECTING OAK DECLINE}

\section{Phytophthora}

Plant pathogens of the genus Phytophthora have a global distribution and play a crucial role in damaging both agricultural crops and forest ecosystems (Nilsson and Diunker P. 1997; Oßwald et al. 2014; Milenković et al. 2012). Several Phytophthora species (P. quercina, P. cambivora, P. plurivora, etc.) were linked with the decline phenomenon of oak trees. The level of fine root damage often reaches $90 \%$ or more (Fig. 1).

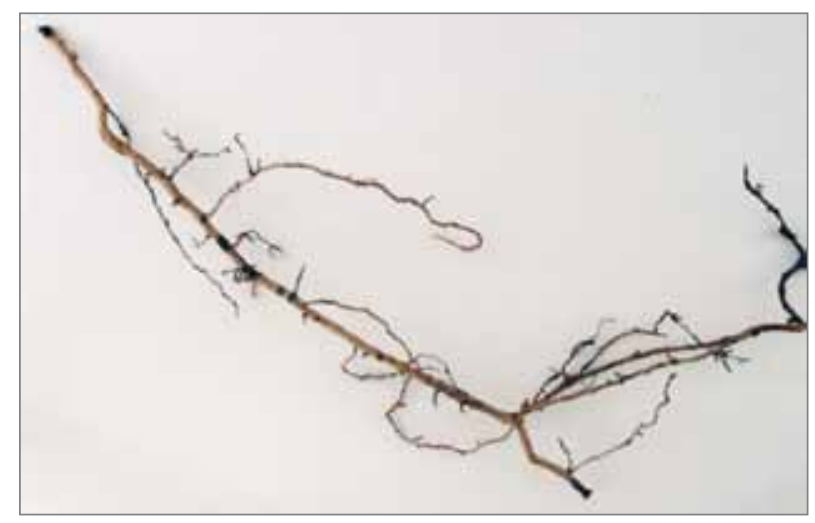

Figure 1. Fine roots of pedunculate oak (over 100-year-old), damaged in $90 \%$

Those species are able to infect both juvenile and mature pedunculate (Quercus robur L.) or sessile oak (Q. petraea Liebl.) trees and affect their vitality by decreasing their photosynthesis, the growth of roots and their functionality (Jönsson et al. 2003, Barajas-Morales et al. 1997). An invasive pathogen such as P. cinnamomi, which can potentially deteriorate the health status of Mediterranean oak trees (Oszako and Orlikowski 2005), has been recently discovered at a high incidence in the study of three native pedunculate oak forests in Poland (unpublished 2015). However, P. cinnamomi was recorded on pedunculate oaks in Poland already in 2005 (Oszako and Orlikowski 2005). As this pathogen is highly dependent on soil water content and mild temperatures, a combination of observed climate warming and frequent weather extremes could enhance the decline process of the abovementioned populations of oaks, which is of much concern for local foresters. 


\section{Armillaria}

The Armillaria species are opportunistic pathogens that cause damage to a wide range of woody hosts (Shaw and Kile 1991; Fox et al. 2000). Usually, they attack the already stressed oaks and cause decay in the main roots and the sapwood. These fungal species demonstrate different levels of their pathogenicity, which is highly correlated with the production of rhizomorphs (Morrison 2004). The shift in the pathogenicity of opportunistic pathogens, Armillaria gallica (Fig. 2) and A. cepistipes, was observed in Europe during the oak decline incidents in the past (Keča et al. 2006; 2009; Lushaj et al. 2010; Keča and Solheim 2011; Cleary eta 1. 2012, Cleary and Holmes 2011). They also often follow damage that Phytophthora causes to fine roots infecting the vicinity of cankers occurring on mother roots (Fig. 3).

\section{Insect defoliators}

The insect defoliators regularly cause damage to oaks and other broadleaf forest tree species, particularly in the Northern Hemisphere. A recent study showed that the leaves of Quercus rubra L., naturally infected by Phytophthora plurivora are more susceptible to an attack by Lymantria dispar L., than leaves of healthy trees (Milanović et al. 2015).

\section{Oak decline phenomena and research gaps}

There are considerable knowledge gaps about the oak decline phenomenon; especially processes leading to the deterioration of tree health and possible death are barely investigated. The visible symptoms of disorders are often too general and therefore it becomes difficult to find practical solutions to mitigate its consequences. In particular, there is little understanding of how the extreme weather conditions influence the subtle interaction between the local population of tree-hosts, pathogens and insect pests. How do host-pathogen interactions change if abiotic stress disrupts physiological processes in oaks? It is of major importance to recognise the decline process in the initial phase, because once the decline syndrome starts, it is hard to stop its further development. Also the involvement of contributing factors such as secondary insect pests (Cerambyx spp., Agrillus spp., Scolytus intricatus (Ratz.) (Coleoptera: Scolyti-

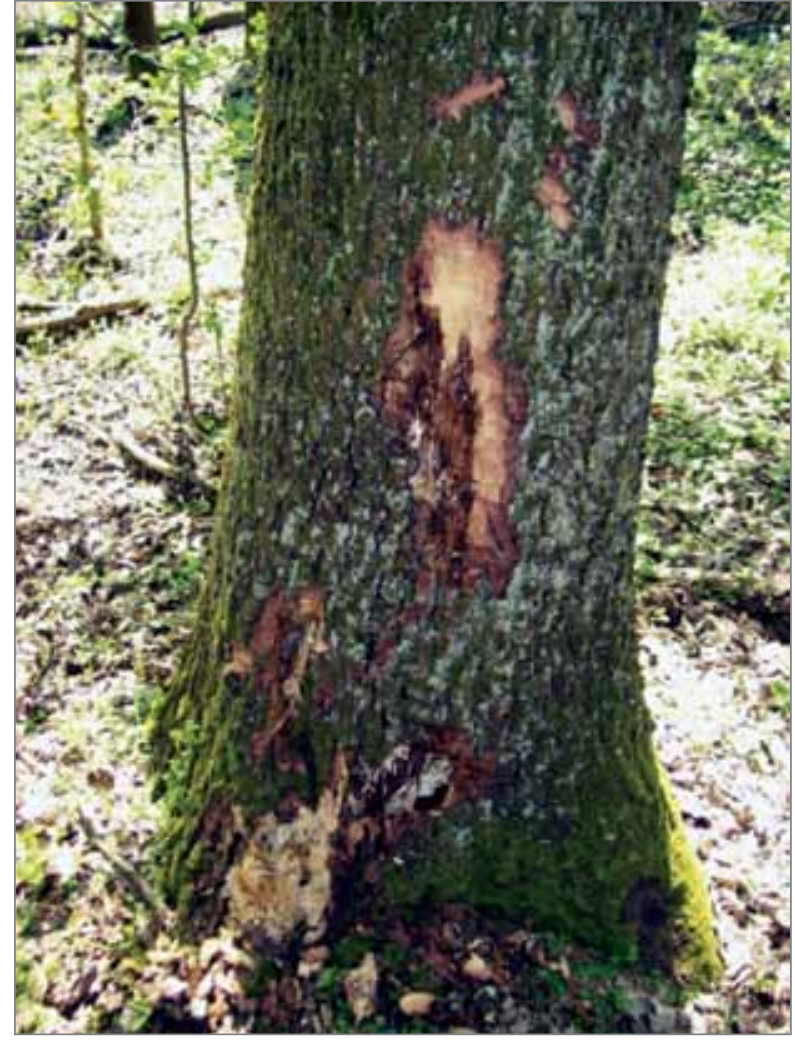

Figure 2. Mycelial fans of Armillaria gallica developing under the bark od declining oak trees

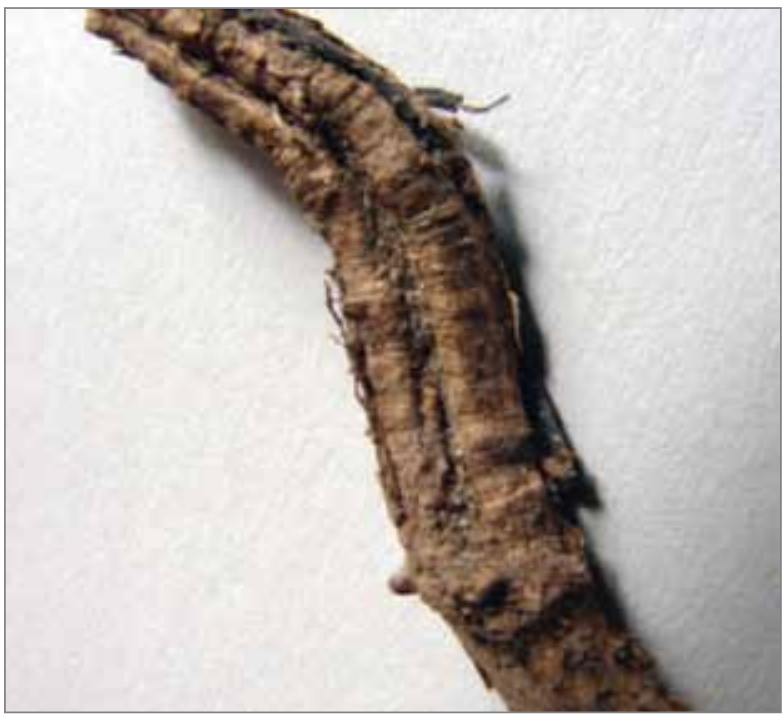

Figure 3. Lateral roots completely damaged by pathogens of Phytophthora genus. The canker (in the middle) is being healed by callus tissues (from both sides) but rhizomorphs of Armillaria sp., which are attached to the root surface, (above) started secondary infection 
nae), etc. or stem-decaying fungi (Fomes fomentarius (L.) J.J. Kickx, Kretzschmaria deusta (Hoffm.) P.M.D. Martin (Fig. 4), Stereum spp., Trametes spp., Phellinus igniarius (L.) Quél. and P. robustus (P. Karst.) Bourdot $\&$ Galzin, etc) is usually hard to prevent.

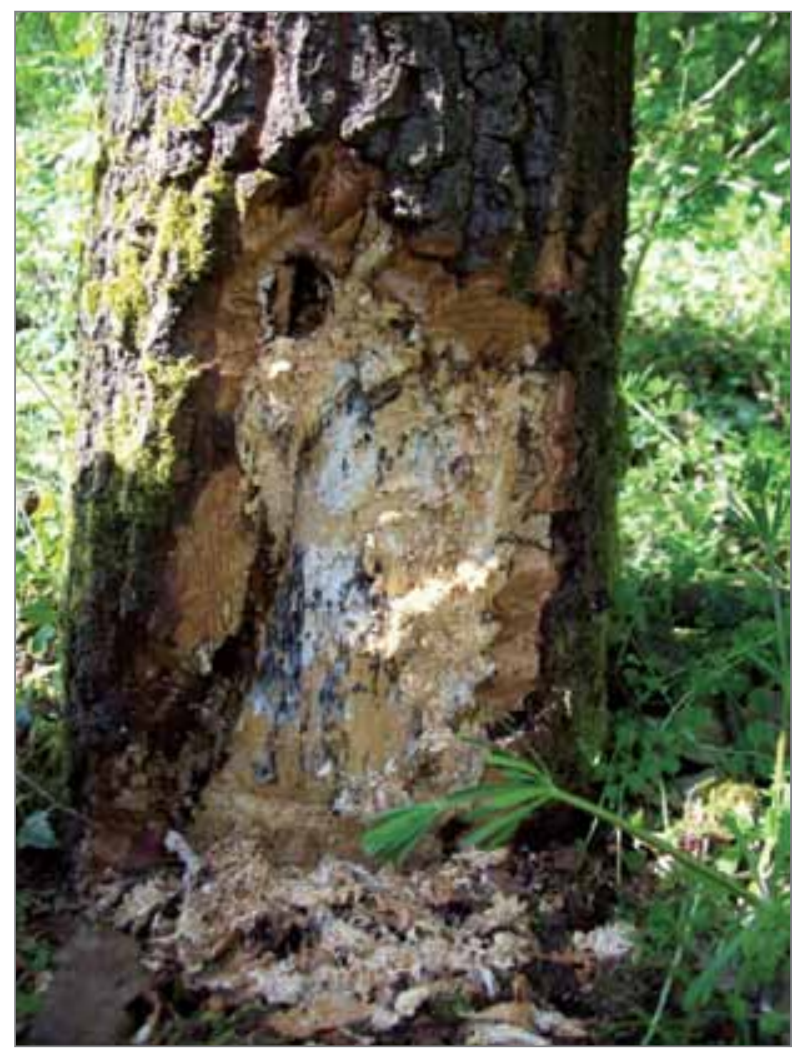

Figure 4. Mycelium of Kretzschmaria deusta destroying bark and wood of stressed oak trees

Oak decline phenomena are complex, multi-factor disease, resulting in a progressive weakening of trees and leading to the dieback of their crowns (Manion and Lachance 1992). In their study, they observed the loss of vitality of oaks and the reduction in their growth rate, as well as an increase in their susceptibility to abiotic and biotic stressors. The decline syndromes generally affect trees of all age classes and ultimately cause their death, unless the stress is removed (Woo 2009). Though many researchers had studied forest decline from different points of view, the main cause of this widespread phenomenon is still not well understood. In the light of effects of climatic factors (single or combined), such as summer drought or heavy rains, the decline of trees, in particular oaks, could be even more readable in the course of the 21st century. Knowledge of physiological processes accompanying different disorders, ultimately leading to the mortality of oaks, is crucial to understand their susceptibility to predisposing (soil properties, drought, stand structure, etc.), inciting (primary insects, oak mildew, winter frost, etc.) and contributing (root rot diseases, stem decay fungi, secondary insect pests, etc.) factors (Figs. 3 and 4) (Ceisla and Donauber 1994). To understand this complex process, the factors contributing to the decline process and their interactions under controlled conditions need to be separately tested. The susceptibility of pedunculate oak (Q. robur) to climate extremes like drought/ flood, followed by the root infection with the native pathogens like Armillaria gallica, P. plurivora or the invasive one as $P$. cinnamomi, is still unclear. The decline process is strongly correlated with the destruction or decay of the root system and crown defoliation (Figs. 1 and 2). However, in the case of mature trees, it is very hard to find any correlation between the amount of decayed roots and symptoms observed in their crowns.

Armillaria gallica is the native pathogen to oak stands representing an opportunistic species that attacks stressed trees and coarse roots, while $P$. plurivora is a biotroph that colonises mainly fine roots. It is still unknown if the loss of the fine roots will have a stronger influence on the decline of stressed trees, e.g. by insect defoliators, than the loss of the coarse roots. Also, there is evidence that the synergistic activity of both pathogens may occur during the decline of oaks (Jung et al. 2016; Oßwald et al. 2014; Keča et al. 2015). The invasive $P$. cinnamomi could cause much more serious problems if it is introduced in a new ecosystem, similar to as it was observed in oak stands (Quercus coccifera L., Q. ilex L. and Q. suber L.) in the Mediterranean region (Brasier 1996; Brasier and Scott 1994; Corcobado et al. 2014; Linaldeddu et al. 2014).

\section{Physiological aspects of tree reaction TO DROUGHT AND PEST ATTACK}

The high carbon availability during the root growth should increase an oak's defence capacity against the root pathogens (Jönsson 2006). Another study showed that the ability of trees to mobilise non-structural carbohydrates against root-rot pathogens enhances its susceptibility and speeds up the decline process (Angay 
et al. 2014). So, there is no consensus reached on the influence of photosynthetic assimilates (simple sugars) on the activity of harmful organisms (insect defoliators, fungi, Oomycetes).

The root pathogens strongly influence the water relations in the woody plants, which particularly implies the transpiration and photosynthesis of leaves. The measurements of gas exchange and the fluorescence of leaves may be used to calculate the electron transport rate (Laisk and Loreto 1996). The differences between the electron transport rate calculated from the fluorescence ratio and that calculated from the gas-exchange measurements have been used to estimate the mesophyll diffusion resistance and chloroplast $\mathrm{CO}_{2}$ concentration and non-photosynthetic carboxylation and decarboxylation rates. These parameters could be used for an assessment of the process of photosynthesis and the health condition of oaks.

Furthermore, plant hormones, like abscisic acid (ABA), play an important role in many aspects of plant growth. The adaptation to drought and low temperatures is regulated by the combinatorial activity of interconnected ABA-dependent and ABA-independent signalling pathways (Mauch-Mani and Mauch 2005). By contrast, the plant hormones like salicylic acid (SA), the jasmonate acid (JA) and the ethylene (ET) play a major role in the trees' resistance to pathogens and insects (Flors et al. 2008). The combination of these hormones could be crucial in the assessment of the stress in trees as well as in the resistance/susceptibility of trees to later pest attacks (Thaler and Bostock 2004).

\section{Genetic Variation Vs health state OF OAK STANDS}

Thirteen oak ( $Q$. robur) populations from the Krotoszyn and Elblag Forest Districts, located in central and northern Poland (51 $68^{\prime} \mathrm{N}, 17^{\circ} 44^{\prime} \mathrm{E}$ and $54^{\circ} 20^{\prime} \mathrm{N}, 1^{\circ} 73^{\prime} \mathrm{E}$, respectively), were analysed in order to determine genetic variation and similarity in relation to health and resistance to stress factors (Nowakowska et al. 2007). Chloroplast DNA was investigated using PCR-RFLP markers. Different frequencies of six haplotypes variants (' 1 ', ' 4 ', '5', '7', '10' and '12') of 'DT' and 'CD' loci primers were determined. All oak populations studied were characterised by high genetic variation $\left(\mathrm{G}_{\mathrm{ST}}=0.818\right)$, which indicate higher genetic variation observed within the stand than among them (Nowakowska et al. 2007). Going into details, higher genetic variation was observed in trees from central Poland (Krotoszyn; $\mathrm{H}_{\mathrm{T}}=0.809$ ) in comparison to the northern part (Elbląg; $\mathrm{H}_{\mathrm{T}}=0.785$ ). Oaks stands from Krotoszyn mostly originated from the Balkan and Iberian oak refugees, as demonstrated by the presence of prevalent haplotype pattern composed of variants ' 5 ', ' 10 ' and ' 12 ', respectively. Within this region, noticeably Jarocin stand was composed by trees with one Balkanian haplotype ' 7 ' to the extent of $87 \%$. Conversely, most stands of the Elbląg Forest Region presented the haplotype pattern typical of the Apennines post-glacial oak refuge (with predominating variants ' 10 ' and ' 12 '). One population from this region, Młynary, exhibited slightly different pattern with a high proportion of Balkanian haplotype ' 4 ' $(40 \%)$ and Iberian haplotype '12' (38\%).

Within these oak populations, Jarocin (Krotoszyn FD) and Młynary (Elbląg FD), stand health was monitored from 1999. Different levels of injury symptoms were observed between stands but mortality was higher in Jarocin, less genetically variable (with predominant frequency of one Balkanian haplotype '7'). Severe damage affected $60 \%$ of the trees in Jarocin stand after 2003 , which was probably due to a combination of unfavourable climatic conditions and infection by pathogens, e.g. Phytophthora and Pythium. It has been shown that in Poland, oak trees have been colonised mainly by $P$. quercina, $P$. cactorum, $P$. plurivora, $P$. cambivora and P. cinnamomi (Oszako and Orlikowski 2005; Jankowiak et al. 2014; Nowakowska et al. 2016). Comparing chloroplast DNA variation data obtained for Młynary from central Poland and Jarocin from northern Poland, the population with higher cpDNA differentiation (Młynary) appeared better adapted to the changing environmental conditions (drought, high temperature) than Jarocin with lower genetic variation (Nowakowska et al. 2007).

\section{RECOMMENDATIONS FOR FURTHER RESEARCH}

Further research has to be done in order to determine (i) measurable factors that can indicate that the process of tree decline has already started, (ii) the correlation between the root decay and the crown symptoms, 
(iii) which combination of stressors stimulate the best development of pathogens leading to high plant mortality, (iv) the difference between the mortality caused by the native and the invasive pest species.

\section{ACKNOWLedgements}

The research was performed within the frame of LIFE+ ENV/PL/000459 HESOFF ongoing European project 'Evaluation of the health state of forests and an effect of phosphate treatments with the use of photovoltaic unmanned aerial vehicle (UAV)'.

\section{References}

Angay O., Fleischmann F., Recht S., Herrmann S., Matyssek R., Oßwald W., Buscot F., Grams, T.E.E. 2014. Sweets for the foe - effects of non-structural carbohydrates on the susceptibility of Quercus robur against Phytophthora quercina. New Phytologist, 203, 1282-1290.

Barajas-Morales J., Perez-Jimenez L.A., Chiang F. 1997. Seasonal fluctuations of starch in wood and bark of trees from a tropical deciduous forest in Mexico. Anales del Instituto de Biologia, Universidad Nacional Autonoma, de Mexico,Serie Botanica,, 68 (1), 7-19.

Borja I., De Wit H.A., Steffenrem A., Majdi J. 2008. Stand age and fine root biomass, distribution and morphology in Norway spruce chronosequence in southeast Norway. Tree Physiology, 28, 773-784.

Brasier C.M. 1996. Phytophthora cinnamomi and oak decline in southern Europe. Environmental constraints including climate change. Annales des Sciences Forestieres, 53 (2-3), 347-358.

Brasier C.M., Scott J.K. 1994. European oak declines and global warming: a theoretical assessment with special reference to the activity of Phytophthora cinnamomi. EPPO Bulletin, 24(1), 221-232.

Ceisla W.M., Donauber E. 1994. Decline and dieback of forest trees and forests. A global overview. FAO Forestry Papers, 120, 90 pp.

Cleary M.R., van der Kamp B.J., Morrison D.J. 2012. Pathogenicity and virulence of Armillaria sinapina and host response to infection in Douglas-fir, west- ern hemlock, and western red cedar in the southern interior of British Columbia. Forest Pathology, 42, 481-491.

Cleary M, Holmes T. 2011. Traumatic resin duct formation in the phloem of western red cedar (Thuja plicata) following abiotic wounding and infection by Armillaria ostoyae. IAWA, 32, 351-359.

Corcobado T., Cubera E., Juárez E., Moreno G., Solla A. 2014. Drought events determine performance of Quercus ilex seedlings and increase their susceptibility to Phytophthora cinnamomi. Agricultural and Forest Meteorology, 192-193, 1-8.

Flors V., Ton J., Van Doorn R., Jakab G., GarcíaAgustín P., Mauch-Mani B. 2008. Interplay between JA, SA and ABA signalling during basal and induced resistance against Pseudomonas syringae and Alternaria brassicicola. The Plant Journal, 54 (1), 81-92.

Fox R.T.V. 2000. Armillaria root rot: Biology and Control of Honey Fungus. Intercept Limited (Scientific, Technical and Medical Publishers), Andover, Hants., U.K. pp. 222.

Jönsson U., Jung T., Rosengren U., Nihlgard B., Sonesson K. 2003. Pathogenicity of Swedish isolates of Phytophthora quercina to Quercus robur in two different soils. New Phytologist, 158, 355-364.

Jönsson U. 2006. A conceptual model for the development of Phytophthora disease in Quercus robur. New Phytologist, 171, 55-67.

Jankowiak R., Stepniewska H., Bilański P., Kolařík M. 2014. Occurrence of Phytophthora plurivora and other Phytophthora species in oaks forests of southern Poland and their association with site conditions and the health status of trees. Folia MIcrobiol (Praha), 59 (6), 531-542.

Jung T., Orlikowski L., Henricot B., Abad-Campos P., Aday A.G., Aguín Casal O., Bakonyi J., Cacciola S.O., Cech, T., Chavarriaga D., Corcobado T., Cravador A., Decourcelle T., Denton G., Diamandis S., Doğmuş-Lehtijärvi H.T., Franceschini A., Ginetti B., Green S., Glavendekić M., Hantula J., Hartmann G., Herrero M., Ivic D., Horta Jung M., Lilja A., Keča N., Kramarets V., Lyubenova A., Machado H., Magnano di San Lio G., Mansilla Vázquez P.J., Marçais B., Matsiakh I., Milenkovic I., Moricca S., Nagy Z.Á., Nechwatal J., Olsson C., Oszako T., Pane A., Paplomatas E.J., Pintos Varela C., Prospero S., Rial Martínez C., Rigling D., 
Robin C., Rytkönen A., Sánchez M.E., Sanz Ros A.V., Scanu B., Schlenzig A., Schumacher J., Slavov S., Solla A., Sousa E., Stenlid J., Talgø V., Tomic Z., Tsopelas P., Vannini A., Vettraino A.M., Wenneker M., Woodward S., Peréz-Sierra A. 2016. Widespread Phytophthora infestations in European nurseries put forest, semi-natural and horticultural ecosystems at high risk of Phytophthora diseases. Forest Pathology, 46, 134-163.

Keča N., Bodles W.J.A., Woodward S., Karadžić D., Bojovic S. 2006. Molecular-based identification and phylogeny of Armillaria species from Serbia and Montenegro. Forest Pathology 36, 41-57.

Keča N., Karadžić D., Woodward S. 2009. Ecology of Armillaria species in managed forests and plantations in Serbia. Forest Pathology, 39, 217-231.

Keča N., Solheim H. 2011. Ecology and distribution of Armillaria species in Norway. Forest Pathology, 41, 120-132.

Keča N., Klopfenstein N.B., Kim M.S., Solheim H., Woodward S. 2015. Initial characterization of an unidentified Armillaria isolate from Serbia using LSU-IGS1 and TEF-1- $\alpha$ genes. Forest Pathology, 45, 120-126.

Laisk A., Loreto F. 1996. Determining photosynthetic parameters from leaf $\mathrm{CO}_{2}$ exchange and chlorophyll fluorescence. Plant Physiology, 110, 903-912.

Linaldeddu B.T., Scanu B., Maddau L., Franceschini A. 2014. Diplodia corticola and Phytophthora cinnamomi: the main pathogens involved in holm oak decline on Caprera Island (Italy). Forest Pathology, 44, 191-200.

Lindner M., Maroschek M., Netherer S., Kremer A., Barbati A., Garcia-Gonzalo J., Seidl R., Delzon S., Corona P., Kolström M., Lexer M.J., Marchetti M. 2010. Climate change impacts, adaptive capacity, and vulnerability of European forest ecosystems. Forest Ecology and Management, 259, 698-709.

Lushaj B.M., Woodward S., Keča N., Intini M. 2010. Distribution, ecology and host range of Armillaria species in Albania. Forest Pathology, 40, 485-499.

Manion P.D., Lachance D. (eds.) 1992. Forest Decline Concepts. APS Press, St. Paul, MN, 249 pp.

Masters G.J., Brown V.K., Gange A.C. 1993. Plant mediated interactions between above and belowground insect herbivores. Oikos, 66, 148-151.
Mauch-Mani B., Mauch F. 2005. The role of abscisic acid in plant-pathogen interactions. Current Opinion in Plant Biology 8, 409-414.

Milanović S., Lazarević J., Karadžić D., Milenković I., Jankovský L., Vuleta A., Solla A. 2015. Below ground infections of the invasive Phytophthora plurivora pathogen enhance the suitability of red oak leaves to the generalist herbivore Lymantria dispar. Ecological Entomology, 40, 479-482.

Milenković I., Keča N., Karadžić D., Nowakowska J., Borys M., Sikora K., Oszako T. 2012. Incidence of Phytophthora species in beech stands in Serbia. Folia Forestalia Polonica, series A, 54 (4), 223-232.

Morrison D. 2004. Rhizomorph growth habit, saprophytic ability and virulence of 15 Armillaria species. Forest Pathology, 34, 15-26.

Nilsson S., Diunker P. 1997. The extent of forest decline in Europe. Environment, 29, 4-31.

Nowakowska J.A., Oszako T., Bieniek J., Rakowski K. 2007. Genetic characterization in relation to the health state of oak populations in the Elbląski and Krotoszyński regions of Poland (in Polish with English summary). Leśne Prace Badawcze, 3, 33-51.

Nowakowska J.A., Malewski T., Oszako T., Tereba A., Borys M. 2016. Molecular diagnostic of Phytophthora pathogens as a tool for Integrated Pest Management (in Polish with English summary). Sylwan, 160 (5), 365-370.

Osswald W., Fleischmann F., Rigling D., Coelho A.C., Cravador A., Diez J., Dalio R.J., Horta Jung M., Pfanz H., Robin C., Sipos G., Solla A., Cech T., Chambery A., Diamandis S., Hansen E., Jung T., Orlikowski L.B., Parke J., Prospero S., Werres S. 2014. Strategies of attack and defence in woody plant-Phytophthora interactions. Forest Pathology, 44, 169-190.

Oszako T., Delatour C. 2000. Recent advances on oak health in Europe. Forest Research Institute, Warsaw, $281 \mathrm{pp}$.

Oszako T., Orlikowski L.B. 2005. First data on the occurrence of Phytophthora cinnamomi on pedunculate oak in Poland (in Polish with English summary). Sylwan, 149 (10), 47-53.

Pautasso M., Döring T.F., Garbelotto M., Pellis L., Jeger M.J. 2012. Impacts of climate change on plant diseases - opinions and trends. European Journal of Plant Pathology, 133, 295-313. 
Portz R.L., Fleischmann F., Koehl J., Fromm J., Ernst D., Pascholati S.F., Osswald W.F. 2011. Histological, physiological and molecular investigations of $\mathrm{Fa}-$ gus sylvatica seedlings infected with Phytophthora citricola. Forest Pathology, 41, 202-211.

Richardson A.D., Keenan T.F., Migliavacca M., Ryu Y., Sonnentag O., Toomey M. 2013. Climate change, phenology, and phenological control of vegetation feed-backs to the climate system. Agricultural and Forest Meteorology, 169, 156-173.

Santini A., Ghelardini L., De Pace C., Desprez-Loustau M.L., Capretti P., Chandelier A., Cech T., Chira D., Diamandis S., Gaitniekis T., Hantula J., Holdenrieder O., Jankovsky L., Jung T., Jurc D., Kirisits T., Kunca A., Lygis V., Malecka M., Marcais B., Schmitz S., Schumacher J., Solheim H.,
Solla A., Szabò I., Tsopelas P., Vannini A., Vettraino A.M., Webber J., Woodward S., Stenlid J. 2013. Biogeo-graphical patterns and determinants of invasion by forest pathogens in Europe. New Phytologist, 197, 238-250.

Shaw C.G. III, Kile G.A. 1991. Armillaria root disease. United States Department of Agriculture-Forest Service Handbook No. 691. United States Department of Agriculture-Forest Service Washington, DC, USA.

Thaler J.S., Bostock R.M. 2004. Interactions between abscisic-acid-mediated responses and plant resistance to pathogens and insects. Ecology, 85, 48-58.

Woo S.Y. 2009. Forest decline of the world: A linkage with air pollution and global warming. African Journal of Biotechnology, 8 (25), 7409-7414. 